\title{
Blame and contention: how perceptions of the government's role in the economic crisis shape patterns of political action
}

\author{
Marco Giugni $^{1} \cdot$ Maria T. Grasso ${ }^{2}$
}

Published online: 13 December 2017

(C) Macmillan Publishers Ltd., part of Springer Nature 2017. This article is published with open access at Springerlink.com

\begin{abstract}
In this paper we analyse the extent to which perceptions of the government's role in the economic crisis impacted on the political behaviour of European citizens. This includes contentious political activities such as attending public meetings, participating in demonstrations, and joining strikes, but also electoral behaviour in the form of voting against the incumbent. We examine data from 2015 since it allows us to examine European nations experiencing different economic conditions as a result of the 2008 financial crisis and the subsequent period of recession. We find that individuals who blamed the national government for the economic crisis and who were more unsatisfied with the government's handling of unemployment were more likely to participate. However, the effect of these variables varied across different forms of political behaviour. Moreover, the study provides evidence that the effect of the perceptions of one's own economic situation on political behaviour is conditional upon the perceptions people have of the way in which the government is dealing with the situation, and specifically with unemployment, a key marker of the extent of the negative effects of the economic crisis across European nations.
\end{abstract}

Keywords Political behaviour - Economic perceptions · Blame assignment · Economic adversity · Policy-oriented evaluations

Marco Giugni

marco.giugni@unige.ch

Maria T. Grasso

m.grasso@sheffield.ac.uk

1 Department of Political Science and International Relations, University of Geneva, Boulevard du Pont-d'Arve 40, 1211 Geneva, Switzerland

2 Department of Politics, University of Sheffield, Elmfield, Northumberland Road, Sheffield S10 2TU, UK 


\section{Introduction}

The economic crisis starting in 2008 has led to unemployment growth and shrinking GDP across Europe. About 10 years since its onset, there is great variation in the economic conditions of different countries in Europe. In countries where the crisis hit hardest, Greece and Spain, unemployment is still well over 20\%. On the other hand, where the crisis only had mild effects, as in Germany and Switzerland, it is under 5\%. In the UK and Poland, GDP grew at 2.6 and 3.4\%, respectively, whereas in Italy the economy shrunk by $0.4 \%$ in 2014 . Previous research has shown that the economic downturn affected citizens' support for government intervention (Malhotra and Margalit 2010; Margalit 2013; Popp and Rudolph 2011) and fuelled political protests and a variety of social movements (Bennett 2012; Skocpol and Williamson 2013). Particularly in those countries worst hit, large protests took place as European governments were blamed for the negative economic context (Giugni and Grasso 2015a, 2017a). What were the ways in which European citizens aimed to make their voices heard and criticise government handling of the crisis? Which types of citizens disengaged while others engaged in a variety of political activities? Political science literature has long shown how voters use their judgment about circumstances around them to hold politicians accountable (Fiorina 1981) as well as that citizens use a wide array of institutional and non-institutional modes of engagement (Grasso 2018; Pattie et al. 2004). However, research has tended to either focus on understanding the causes for voter turnout (Lewis-Beck and Stegmaier 2000, 2007; Lewis-Beck and Paldam 2000; Lewis-Beck 1988) or looking at other more contentious political activities such as participating in protests or engaging in social movement activism (Bernburg 2015; Grasso and Giugni 2016b; Rüdig and Karyotis 2013). Moreover, most studies of political participation tend to focus on the classic sociological explanations of participation (Brady et al. 1995; Wolfinger and Rosenstone 1980), disregarding the effects of political attitudes and economic perceptions, blame assignment, and policy-related approval. An effort to fill both gaps has recently been made by Levin et al. (2015) in their study on California before the 2010 General Election. These authors have shown the impact of perceptions of economic conditions, policy-oriented evaluations, and blame assignment on involvement in a variety of political activities. In this paper, we take a broader comparative perspective in analysing the extent to which perceptions of the government's role in the economic crisis impacted on different forms of political behaviour of European citizens. We focus in particular on different types of political expressions of dissatisfaction with the current situation, from more mainstream to more confrontational types of political actions: voting against the incumbent, attending public meetings, participating in demonstrations, and participating in strikes. Although voting against the incumbent is not always the result of dissatisfaction with performance rather than a more proactive support of an alternative party or candidate, the four types of political behaviour analysed in this study can all be theorised as at least potential political expressions of dissatisfaction with the current state of things. 
We are particularly interested in examining the impact of two kinds of predictors of political behaviour in the context of economic crisis stressed by previous research: evaluations of the way in which the government deals with one of the most politicised aspects of the crisis-namely unemployment-and blame assignment, more precisely attributing blame for the country's economic difficulties to the government. The latter two aspects in particular capture people's perceptions of the role of the government in the crisis. We suggest, first, that government performance evaluations and blame assignment have a differential effect on distinct forms of political behaviour. Second, we suggest that the way in which people frame the crisis - in terms of blame assignment and satisfaction with the way the government is dealing with it - conditions the effect of the perceptions of one's own economic situation on political behaviour. In addition to investigating the main effects of these two predictors, therefore, we focus our analysis also on the way in which they interact with feelings of relative deprivation.

We focus on nine European countries and analyse data collected by means of an original survey in 2015. These countries shared the experience of the economic crisis to different degrees. Most countries suffered polarisation over disagreements on how to handle the economy and whether to introduce austerity policies or not. Moreover, in some countries voters punished incumbents. At a time where the political context is rife with diverse sources of dissatisfaction, the drivers of political participation may differ in relevant ways between different types of political actions as well as across different kinds of citizens. Exploring these dynamics in a comparative context leads to our paper's novel contribution to existing research. More specifically, we aim to add to the existing literature on political behaviour in three ways. First, we examine the effect of perceptions of the government's role in the economic crisis on different forms of political behaviour, from the more mainstream to the more confrontational, hence allowing for a differentiated approach to the study of political behaviour. Second and relatedly, we study these effects across electoral and non-electoral forms of political behaviour. These aspects have been widely studied in previous research with respect to voting behaviour (Lewis-Beck and Stegmaier 2000, 2007; Lewis-Beck and Paldam 2000; Lewis-Beck 1988), but not so much in the context of non-institutionalised forms of political participation. Thus, we heed recent calls to bridge the gap between the study of electoral politics and that of protest politics (Heaney and Rojas 2014; Hutter 2014; Kriesi 2014; McAdam and Tarrow 2010). Third, continuing a research agenda we begun elsewhere (Giugni and Grasso 2016), we aim to disentangle the way in which deprivation interacts with individual perceptions on the broader political and economic environment to impact on political behaviour in times of crisis. In this paper specifically, we aim to examine how evaluations of the way in which the government deals with unemployment and blame assignment condition the impact of relative deprivation, developing our understanding of the decision to become politically active. 


\section{Previous research and hypotheses}

The literature on the impact of the economy on political activity is extensive but often narrowly focused (Levin et al. 2015). Economic voting theory suggests that individuals reward incumbents when the economy is doing well but punish them when the economy is doing badly (Duch 2007; Hellwig 2010; Lewis-Beck and Paldam 2000; Lewis-Beck and Stegmaier 2000, 2007). Studies have examined both "pocketbook" evaluations of one's own individual or household concerns, including unemployment or whether one struggles to make ends meet and more "sociotropic" concerns about economic adversity affecting one's community or nation, including dissatisfaction with the state of the economy, unemployment, or inflation (Lewis-Beck 1988). By and large, the literature has found very little evidence of a relationship between individual economic problems and voting (Kinder and Kiewiet 1979; Kiewiet 1983; Alvarez and Nagler 1995; Lewis-Beck and Stegmaier 2000).

On the other hand, studies have found that macroeconomic conditions as well as evaluations of how the incumbent has handled the economy do affect voter choice (Lewis-Beck and Stegmaier 2000, 2007; Lewis-Beck and Paldam 2000; Lewis-Beck 1988). This seems at odds with the availability of information: individuals are much more likely to be privy to facts about their own or their household's economic situation than the national economy or government handling of it (Lohmann 1994). Some have explained it by suggesting that the reward-punishment hypothesis only works under conditions where individuals assign responsibility to the government for the situation or think that the government should solve it (Feldman 1982). It also appears that individuals are less likely to hold government responsible for their own economic conditions but more likely to see government responsible for the national economic context (Brody and Sniderman 1977). Kaase and Marsh (1979) had already noted how feelings of deprivation become politicised only where problems appear collectively shared and when political authorities can be blamed or held responsible for the problem.

While the literature had distinguished between pocketbook and sociotropic concerns, it could be perhaps that citizens focus their gaze on specific aspects of the economy such as unemployment or poverty alleviation, rewarding or punishing incumbents depending on how they feel that they have dealt with that specific aspect - thus applying a sort of "policy-oriented economic voting" (Kiewiet 1983; Lewis-Beck and Stegmaier 2000). However, even among studies examining economic perceptions on voting there has not been much work done to analyse the effect of evaluations of action in specific areas (Lewis-Beck and Stegmaier 2000). While scholars study the impact of economic issue preferences-i.e. support for intervention in the economy-it is rarer to find studies of policies or government actions.

In a context of different levels of crisis, examining data from different European countries in 2015 allows us to examine the effect of evaluations of government action on unemployment specifically, perhaps the most politicised negative consequence of the current crisis. The economy has come back as one of the 
main concerns of European publics with the economic crisis. Many European countries were still in dire economic conditions by 2015, particularly those Southern European countries hardest hit by the crisis. In such a situation, levels of support for government tend to fall as they come to be blamed and held responsible for a negative economic context. Government responsibility for economic problems can be understood in different ways: for causing the problem, failing to solve it, or performing at sub-standard level (Iyengar 1991; Peffley 1984; Brody and Sniderman 1977). Blame assignment for economic problems could vary across countries as a function of the different economic conditions and whether one's preferred party is in power. Blame assignment is understood here to have an impact on political participation since it politicises political evaluations (Iyengar 1991; Peffley 1984; Sniderman and Brody 1977) and allows voter to engage in rational retrospective voting (Feldman 1982; Iyengar 1991). Moreover, by connecting personal and social problems to political judgments, blame assignment can act as a psychological cue with profound influences (Iyengar 1991), including on political behaviour.

This leads us to our first hypothesis:

H1 Dissatisfaction with the way the government is dealing with unemployment and blaming the national government for the nation's economic difficulties should spur political participation (direct-effect hypothesis).

While previous research has focused on the impact of evaluations of government performance and blame assignment on voting behaviour, little if any work has been done on how they affect other less institutionalised forms of participation. In our study, we also test for their effect on three further types of activities, namely attending public meetings, participating in demonstrations, and participating in strikes. Given the lack of previous work on these non-electoral forms of participation, we lack a firm ground upon which we can anchor specific hypotheses. However, given the different logics followed by these more contentious forms of political action as opposed to electoral behaviour, we expect perceptions of the government role in the economic crisis to vary across these types of political behaviour. In particular, we suggest that the impact of such perceptions should be stronger when it comes to electoral behaviour and, more specifically, for voting against the incumbent in the context of the crisis. The rationale behind this expectation is that the effect of such behaviour most directly affects those whom the people hold as responsible for the situation.

This leads us to our second hypothesis:

H2 The effect of dissatisfaction with the way the government is dealing with unemployment and blame assignment should be strongest for voting against the incumbent since here the effect of the action will most directly punish the perceived culprits (differential-effect hypothesis).

Our first two hypotheses deal with the direct impact of evaluations of the government role in the economic crisis on different types of political behaviour. We would like to add a third hypothesis concerning the interaction of such evaluations with the way individuals perceive their own economic situation. Particularly in the collective behaviour tradition, relative deprivation theory has typically stressed the 
role of individual grievances and hardship for political behaviour (Davies 1962; Geschwender 1968; Gurr 1970). Subjective perceptions of relative deprivation have been shown to be important in particular for mobilisation to contentious political action (Klandermans et al. 2008), but they are also likely to matter for other forms of expression of political dissatisfaction (Thomassen 1989). The recent economic crisis has revamped this research tradition and led to a number of studies testing the hypothesis that feelings of relative deprivation lead to an increase in protest activities (Grasso and Giugni 2016b; Rüdig and Karyotis 2013; Bernburg 2015).

We suggest that the impact of relative deprivation and, more generally, perceptions of one's own economic situation on political behaviour is conditional upon the perceptions of the government role in the economic crisis. More specifically, dissatisfaction with the way the government is dealing with unemployment and blame assignment are expected to condition the effect of relative deprivation on the four kinds of political behaviour under investigation. A recent study (Grasso and Giugni 2016b) has shown that the impact of individual subjective feelings of deprivation is conditional on contextual macroeconomic and policy factors. This study found that, while individual-level relative deprivation has a direct effect on the propensity to have protested in the last year, this effect is greater under certain macroeconomic and political conditions. By the same token, we may expect perceptions of such macroeconomic and political conditions to play a similar role.

This leads us to our third hypothesis:

H3 Dissatisfaction with the way the government is dealing with unemployment and blame assignment should have a conditional effect on the relationship between relative deprivation and political behaviour, increasing its effect on participation (conditional-effect hypothesis).

In sum, we expect blame assignment and dissatisfaction with the way the government is dealing with unemployment to play an important role for explaining individuals' engagement in different types of political activities, both directly and indirectly through their conditional effect on the relationship between relative deprivation and political behaviour. Further, we expect these two variables to have a greater or lesser impact depending on the specific form of political behaviour at hand, with expected differences between more mainstream and more confrontational forms of political behaviour.

\section{Data and methods}

We use data from an original cross-national survey $(N=18,370)$ fielded in 2015 in the context of the 'Living with Hard Times' (LIVEWHAT) project funded by the European Commission under the auspices of their 7th Framework Programme. The survey was conducted by YouGov in each of the nine European countries included in the project: France, Germany, Greece, Italy, Poland, Spain, Sweden, Switzerland, and the UK. Samples were matched to national statistics for age, gender, region, and education. Since the crisis impacted on the countries to different extents, we also 
Table 1 Variable descriptive statistics

\begin{tabular}{|c|c|c|c|c|}
\hline & Mean & SD & Min & $\operatorname{Max}$ \\
\hline Intends to vote against incumbent & 0.7089489 & 0.45426 & 0 & 1 \\
\hline Attended meeting last 12 months & 0.0965642 & 0.295372 & 0 & 1 \\
\hline Participated in demonstration last 12 months & 0.1110545 & 0.314209 & 0 & 1 \\
\hline Joined strike last 12 months & 0.0558669 & 0.229671 & 0 & 1 \\
\hline Age (mean) & 44.81876 & 14.81204 & 18 & 88 \\
\hline Male & 0.4720666 & 0.499233 & 0 & 1 \\
\hline Education (low) & 0.2406181 & 0.427471 & 0 & 1 \\
\hline Manual occupation & 0.2377314 & 0.425706 & 0 & 1 \\
\hline Unemployed & 0.1172242 & 0.321696 & 0 & 1 \\
\hline Political interest & 0.6431199 & 0.479093 & 0 & 1 \\
\hline Internal political efficacy & 0.4939341 & 0.397554 & 0 & 1 \\
\hline External political efficacy & 0.4792929 & 0.358678 & 0 & 1 \\
\hline Party attachment & 2.529349 & 1.025088 & 1 & 4 \\
\hline Left-right values & 5.239254 & 1.842704 & 0 & 10 \\
\hline Libertarian-authoritarian values & 4.465347 & 1.878585 & 0 & 10 \\
\hline Organisational memberships & 1.253241 & 2.383205 & 0 & 12 \\
\hline Unemployment rate 2014 & 11.92683 & 7.752418 & 4.5 & 26.5 \\
\hline GDP growth 2014 & 1.525811 & 1.124696 & -0.4 & 3.4 \\
\hline Social spending 2014 & 25.20028 & 3.878119 & 19.4 & 31.9 \\
\hline Tax wedge 2014 & 39.83403 & 8.466294 & 22.25 & 49.3 \\
\hline Relative deprivation & 0.4540669 & 0.4979 & 0 & 1 \\
\hline Unsatisfied how government deals with unemployment & 0.8001924 & 0.399867 & 0 & 1 \\
\hline Blames government for economic difficulties & 0.4829909 & 0.499725 & 0 & 1 \\
\hline Disproportionality index & 9.537392 & 5.579571 & 1.25 & 17.66 \\
\hline$N$ & 17,667 & & & \\
\hline
\end{tabular}

include macro-level data from the World Bank on unemployment and GDP growth as well as from the OECD on government social spending and tax wedges as level 2 variables. Descriptive statistics for all the variables are presented in Table 1. Once all missing values are removed, the final sample is 17,667 ( $N$ s for each country are reported in Table 2).

We examine four dependent variables in this study. The first is a dichotomous variable for whether respondents intend to vote for the incumbent party or coalition if there were an election tomorrow. We coded 0 all those who intended to vote for the incumbent and as 1 those who expressed alternative vote choices. The other three dependent variables are measures of participation based on dichotomous variables measuring whether someone had participated in various political activities in the last 12 months. Specifically, we look at attending public meetings, participating in demonstrations, and participating in strikes.

Past research has shown that protest participation has distinct features to other types of political action that could reasonably be classed in the 'unconventional' 


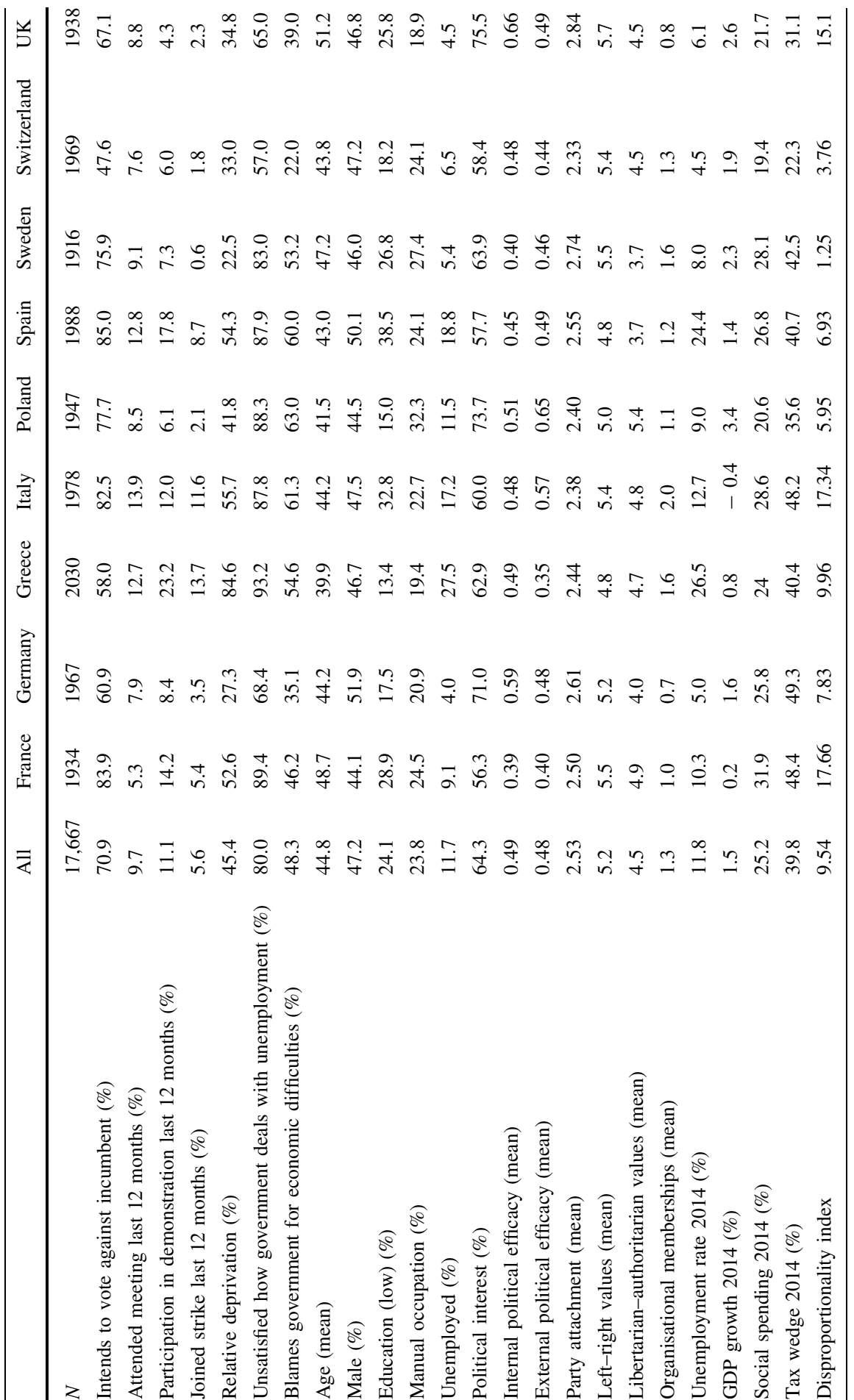


realm (Grasso 2014). As such one alternative is to not create scales of activities but rather focus on this 'modal' expression (Tarrow 1996) of social movement activism - particularly as exhibited by the anti-austerity demonstrations taking place as a result of the crisis. Constructing scales of activities has been applied in studies of participation but these could be problematic, particularly at the cross-national level, and adequate checks must be applied in order to ensure they do not confound very different types of political action (Grasso 2013, 2016a). Moreover, some actions such as petitioning are in some countries even more popular than voting, whereas other forms such as occupying are practised in most European countries only by very tiny fractions of the population (Grasso 2011, 2016b). In this study we therefore opted for measuring protest participation by looking at specific political activities separately. Moreover, since we want to understand the impact of the economic context in 2014 on participation in 2015, we limited the indicators to participation in the last year. On the other hand, for voting the question asked which respondents would vote for if there were an election tomorrow, i.e. future intention to vote. Table 2 shows the proportion of individuals that said they had participated in the various activities in each country or that said they would not vote for the incumbent if there was an election tomorrow. Table 2 also shows that there is reasonable variation. Part of the variation appears to be related to the severity and extent of the crisis. Countries where the crisis had deeper effects such as Greece saw greater levels of protest activism.

Our key independent variable for subjective feelings of relative deprivation is retrospective to the last 5 years so that the deterioration of conditions relative to expectations should have at least begun to occur prior to political behaviour in the last 12 months and as such the time-ordering of independent and dependent variables respects the requirements of causality. This question asks respondents whether they felt that the economic situation of their household was much better or much worse than it was 5 years ago. We dichotomise this measure following previous research (Rüdig and Karyotis 2013) in a dummy for whether individuals felt the economic situation of their household had become worse. Table 2 also shows the proportion of individuals that said the economic situation had become worse in each country. Table 2 shows that there is a good amount of variation also in this respect.

Perceptions of the government's role in the crisis are captured by two variables. On the one hand, to assess the impact of perceptions on specific policy issues, we asked the following question about support for government actions with respect to a specific policy area: unemployment. We coded as 1 those that were unsatisfied with the way the government was dealing with unemployment and 0 the others. On the other hand, to evaluate the influence of blame assignment, we asked the following question about responsibility for the problems: Which of the following do you think are most responsible for the [country]'s economic difficulties? We coded as 1 those selecting "national government" and 0 all others (banks and financial actors, US, European Union, trade unions, migrants, and other). Satisfaction with the government on unemployment and blaming the government for the state of the economy are only weakly correlated at $0.13(p<0.000)$. 
Two macroeconomic variables aim to examine both negative and positive indicators of the economic context. They control for the potential impact that economic hardship, at the aggregate level, has on political behaviour, as posited for example by relative deprivation theory (Grasso and Giugni 2016b). On the one hand, high unemployment levels are perhaps the most pernicious consequence of the current economic crisis in Europe. Countries where unemployment is highest, are those that in general have suffered the most from the current economic crisis. On the other hand, we also examine GDP growth as this is perhaps the clearest measure that a country is doing well and is coming out of recession. Countries with positive and large GDP growth figures are understood to be out of recession and to have curbed the most pernicious effects of the economic crisis. Both variables are taken for 2014 in order to examine conditions prior to participation but not too far back in time. On the policy side, we include two variables linked to austerity policies: the government expenses for social policies (as a percentage of the GDP) and the tax wedge (as a percentage of labour cost). These two variables reflect the definition of austerity policies as reducing government spending, especially in the social realm, and increasing taxation, especially on labour. Research has pointed to the role of public policies as part of the political opportunity structure affecting protest participation (Giugni and Grasso 2015b; Meyer 2004). In this perspective, these two variables control for the potential impact of political opportunities. Again, both are for 2014. In addition, we also control for the effect of different political systems by including Gallagher's disproportionality index. This also captures the fact that voters in different systems might find it easier or harder to assign responsibility for specific policy outcomes to the incumbent, depending on the institutional setup.

We also include in our models the following classic individual-level controls (for more details see, e.g. Dunn et al. 2014; Grasso et al. 2017; Saunders et al. 2012): age, gender, education level (low), occupation (manual), employment status (whether the respondent is unemployed), political interest, internal and external political efficacy, party attachment, left-right values, libertarian-authoritarian values, number of organisational memberships (distributions by country for all dependent and independent variables are provided in Table 2). Socio-demographic characteristics, political attitudes, and organisational involvement have long been shown to play an important role for political participation (Brady et al. 1995; Brady 1999), including party attachment for voting (Campbell et al. 1960). Moreover, research has often argued that more progressive values underpin extra-institutional political participation (Dalton et al. 2010; Welzel and Deutsch 2012).

Our dependent variable is measured at the individual level but we have independent variables at both the individual and the country level. For this reason, we specify multilevel models with random intercept coefficients to take into account the two-level nature of the data (country and individual). This model is useful to correct for the within-country dependence of observations (intraclass correlation) and adjusts both within and between parameter estimates in relation to the clustered nature of the data (Snijders and Bosker 1999). Since our dependent variables are dichotomous, we estimate logistic multilevel models with a Gaussian link function. Although the issue is the object of a debate among methodologists, we use multilevel modelling even if the number of level-2 units is towards the lower end. 
For this reason, we also ran fixed effects models to check for robustness of our results. The results from the latter were effectively the same as those from the multilevel models, so we present the random effects models as a more elegant way of displaying the results and allowing also for the inclusion of the level-2 controls. Moreover, since we hypothesise that the effect of relative deprivation is conditional upon perceptions of the government's role in the crisis - that is, the way people frame it in terms of blame assignment and satisfaction with the way the government is dealing with unemployment-we include in the models, in turn, two interaction terms aimed at capturing these effects.

\section{Results}

Tables 3, 4, 5, and 6 show the results of our analysis. Each table refers to one of the four types of political behaviour under scrutiny: voting against the incumbent, attending public meetings, participating in demonstrations, and joining strikes. We focus our comments on the main effects of satisfaction with the way the government deals with unemployment and of blame assignment (Models 3-5), as well as on the interactions of these two variables and feelings of relative deprivation (Models 6 and 7). The main effects allow us to test our first and second hypotheses, while the interactions allows for examining the evidence for our third hypothesis.

Starting with the main effects, both satisfaction with the way the government deals with unemployment and blame assignment have a significant positive effect on the likelihood to vote against the incumbent (Table 3). Results show that people do not vote for the incumbent when they suffer from poor economic conditions, they think the government is responsible for negative economic conditions in the country, and they are dissatisfied with how it has dealt with the unemployment. Perhaps most importantly, dissatisfaction with the way the government is dealing with the crisis - specifically, with regard to unemployment-has the largest effect, while reducing the effect of relative deprivation when included in the model, showing that perceptions of the government's role in the crisis underlie the key mechanism at work here.

Moving to the three non-electoral forms of participation, we see that people unsatisfied with the way the government deals with unemployment are more likely to attend political meetings, while blame assignment does not seem to matter (Table 4). A similar pattern can be observed for participation in demonstrations (Table 5). As far as the main effects of our two variables are concerned, dissatisfaction with the way the government deals with the crisis displays a significant effect, while blame assignment is not significant. This effect, however, is much less important than for not voting for the incumbent. Finally, joining strikes does not seem to be influenced by dissatisfaction with the way the government deals with the crisis nor by blame assignment, as neither of these two variables has a significant effect (Table 6).

Thus, the analysis of the main effects provides some evidence supporting the first and second hypotheses. As we expected, we observe a direct effect on political behaviour of dissatisfaction with the way the government is dealing with 


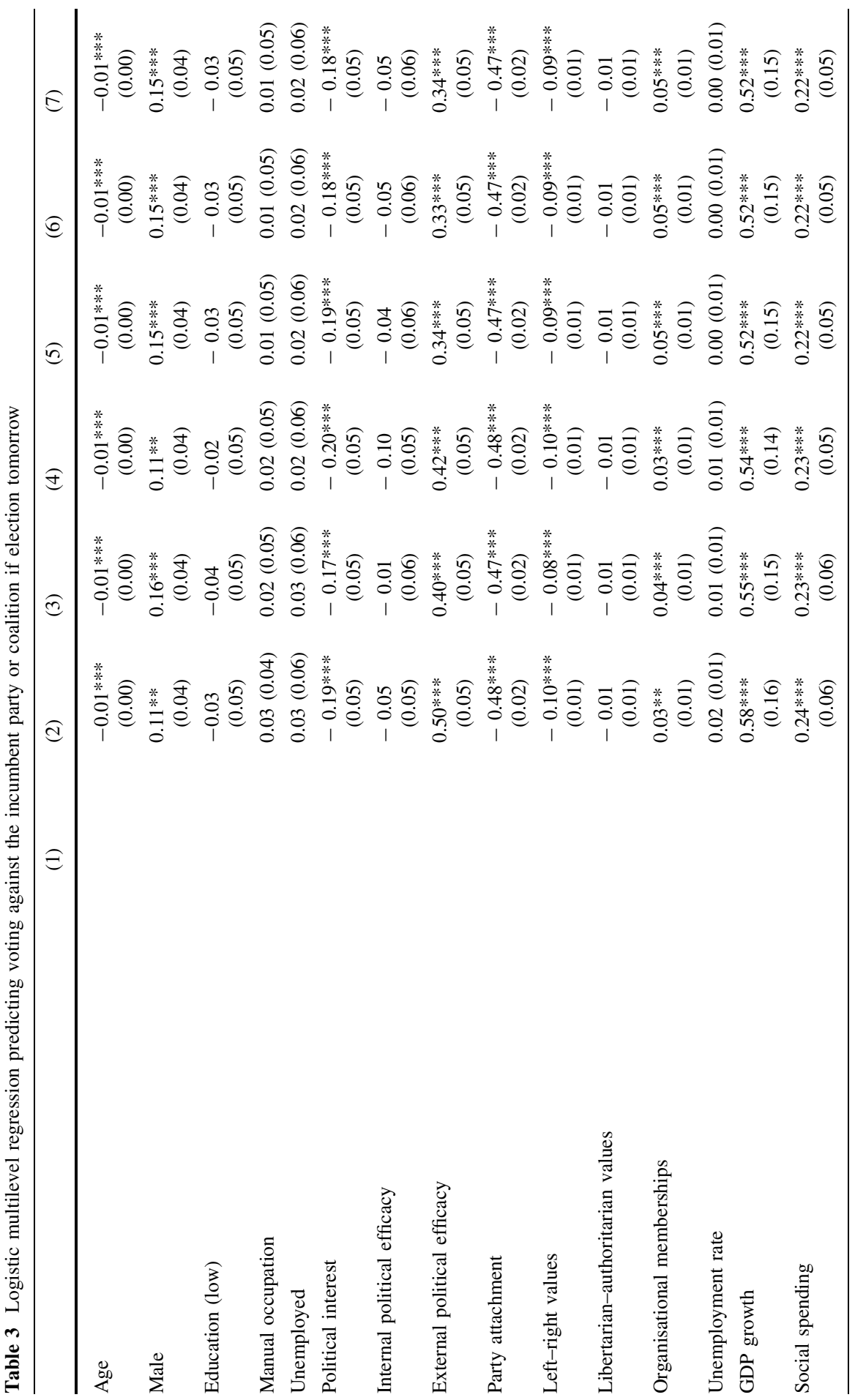




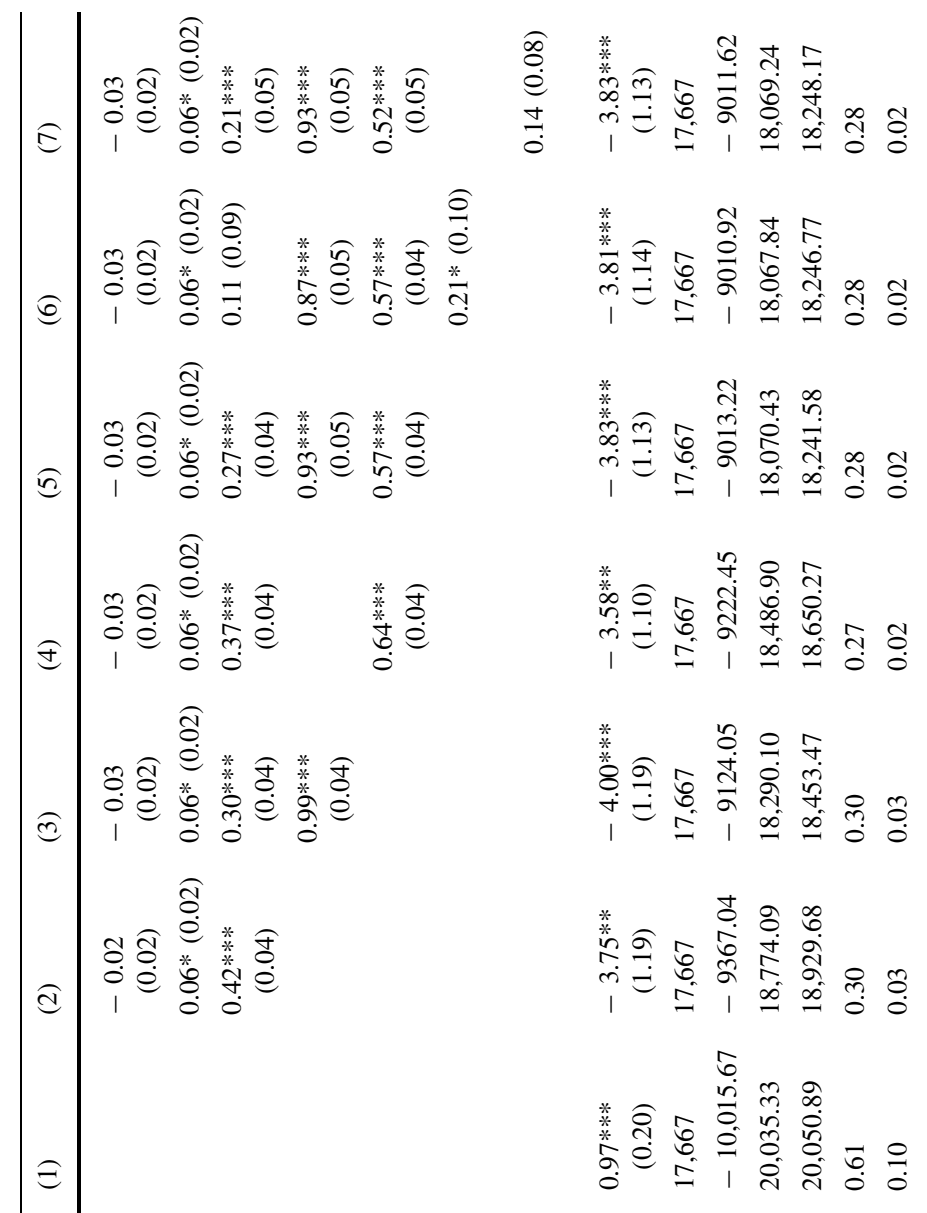

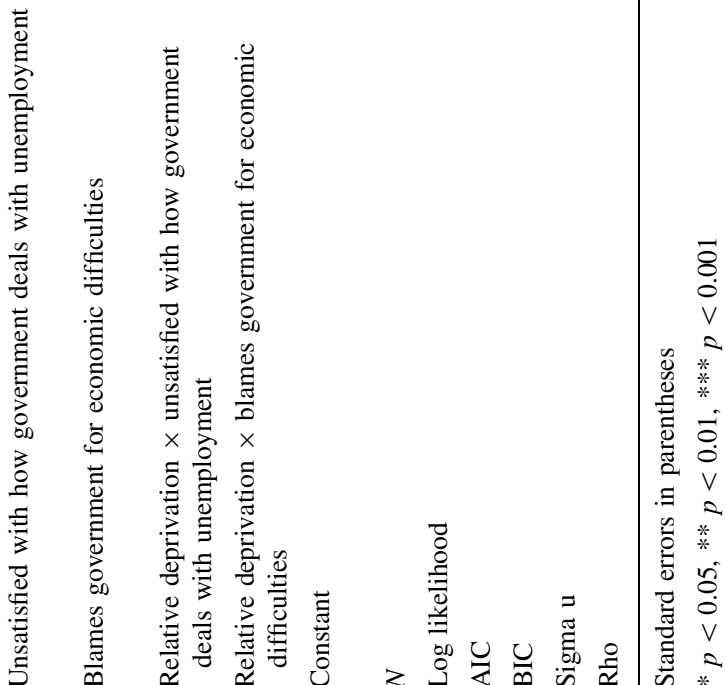




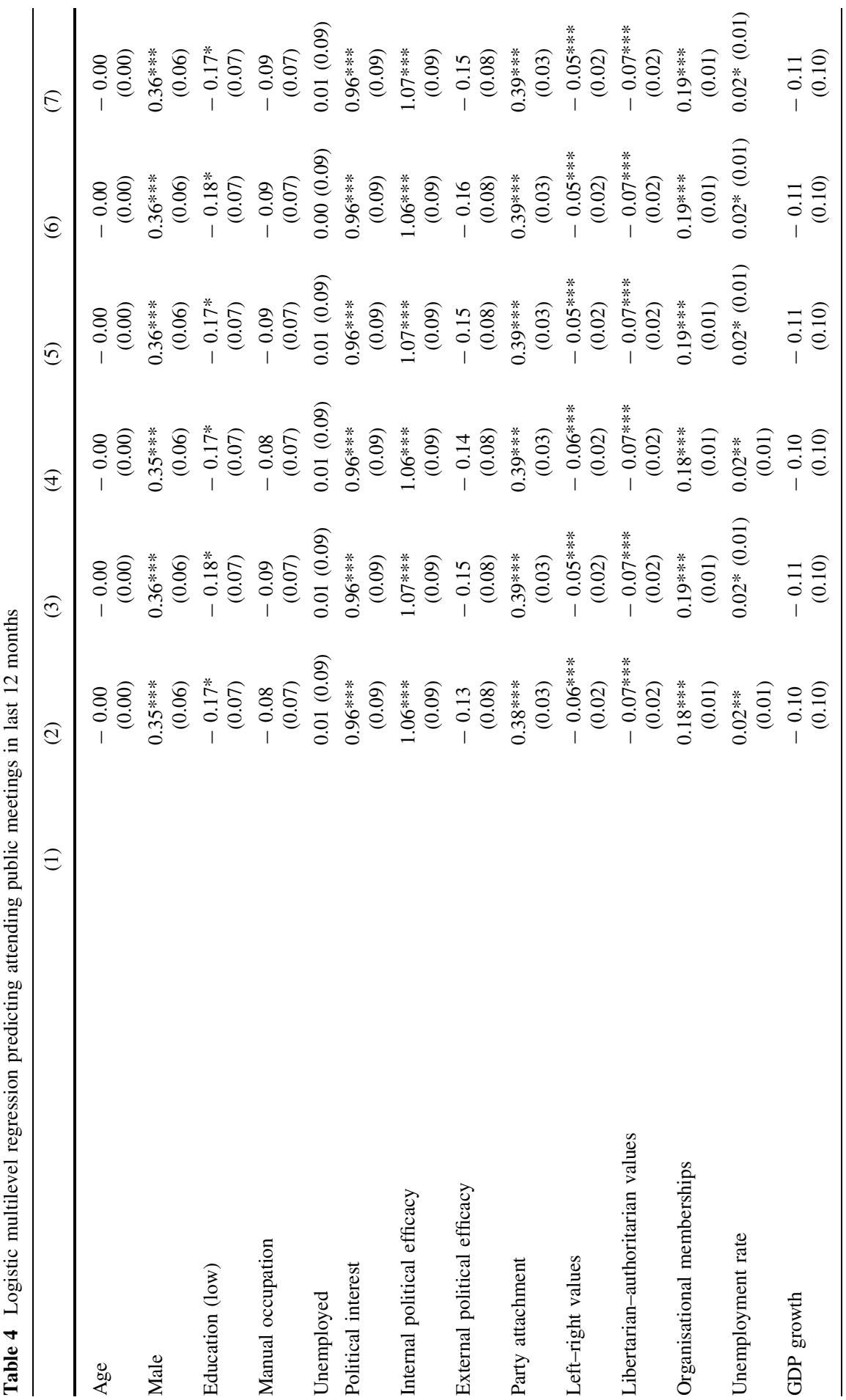




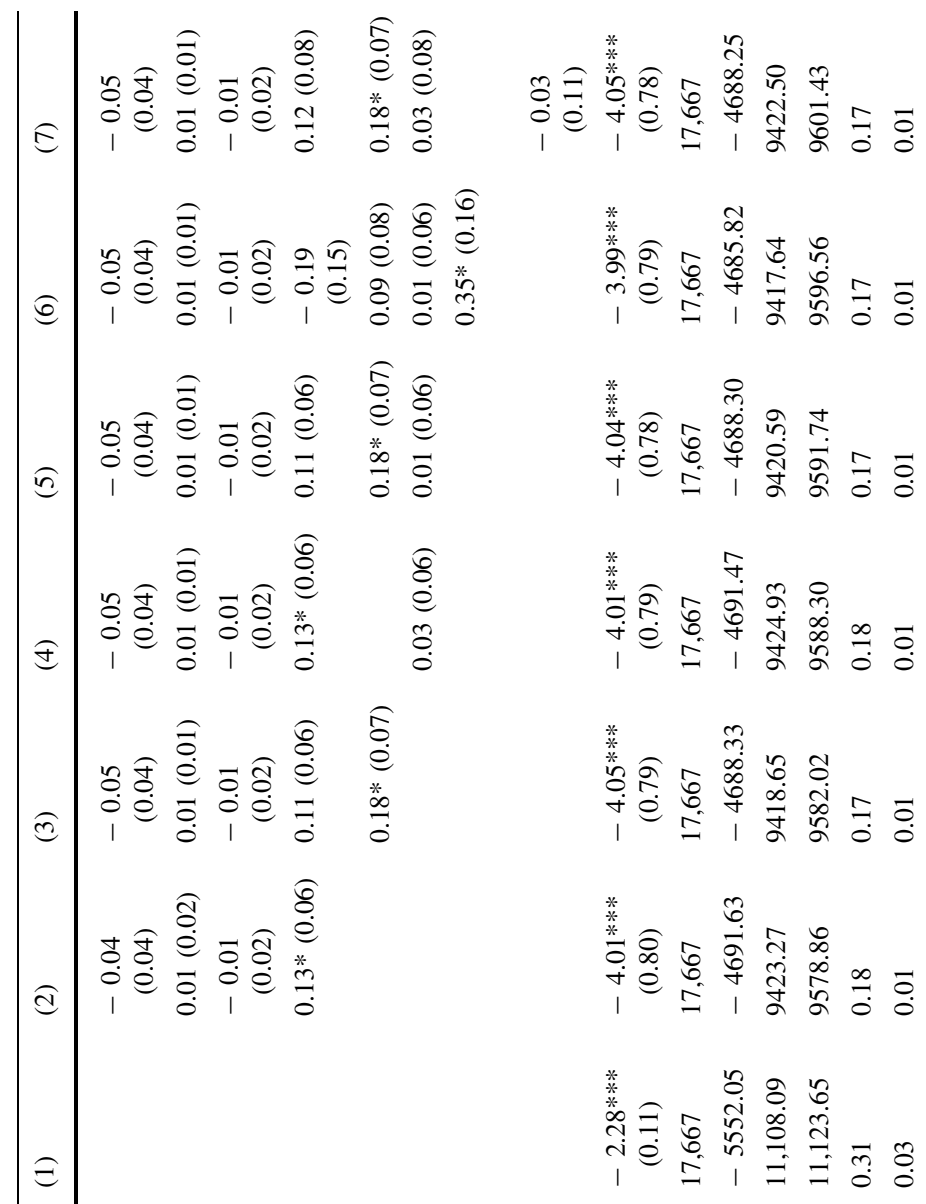

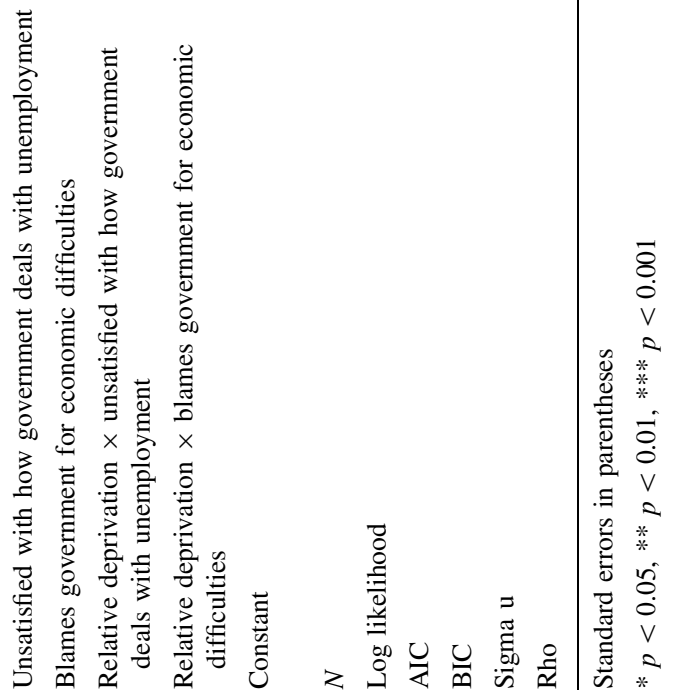




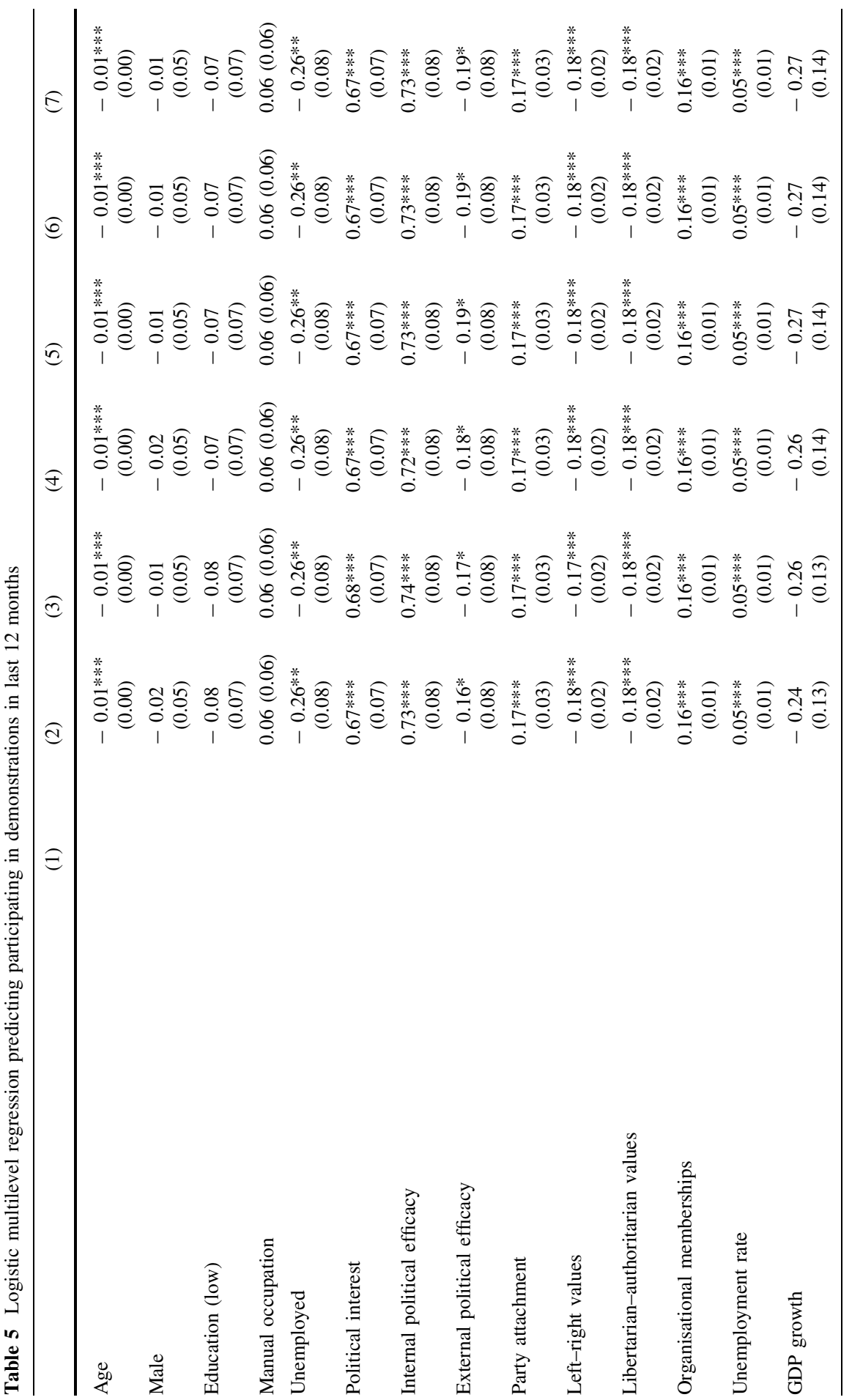




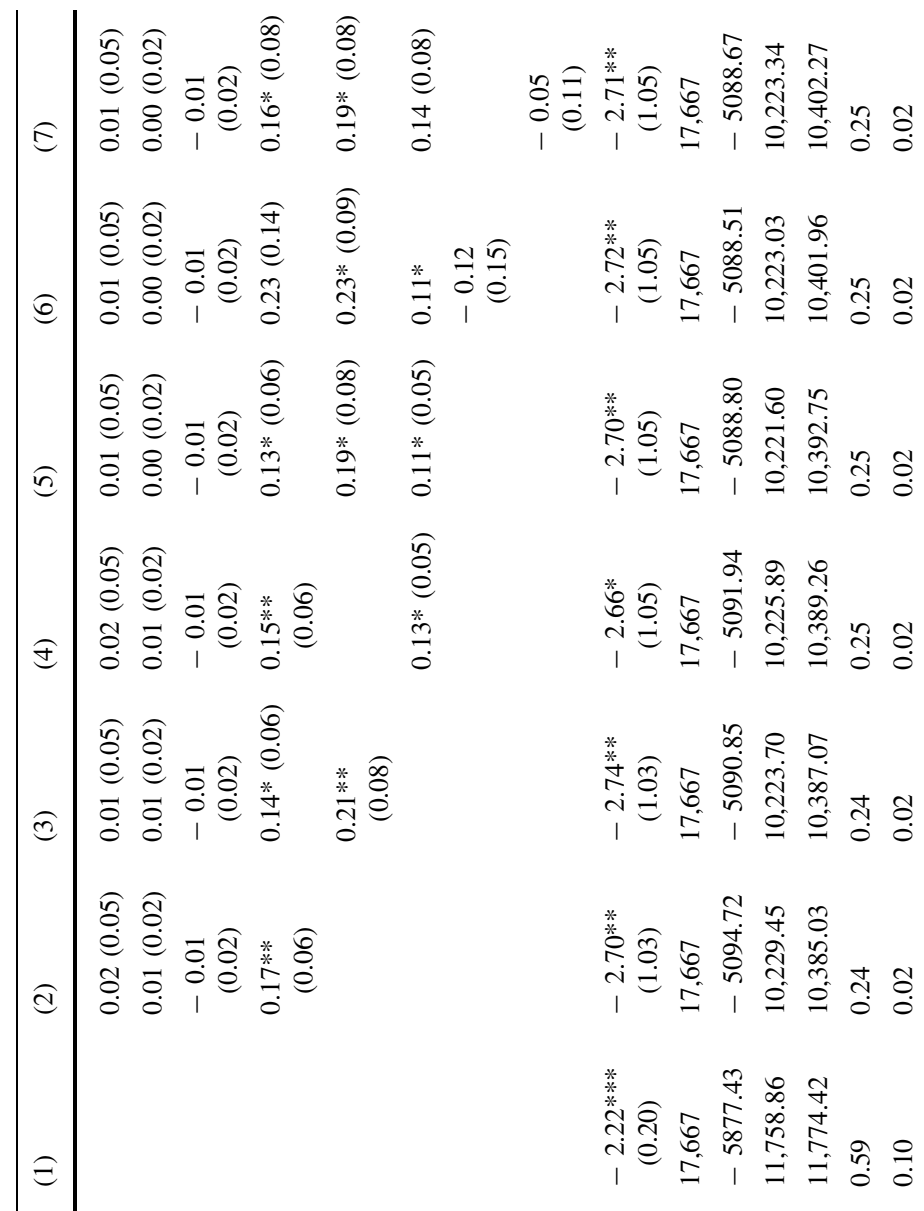

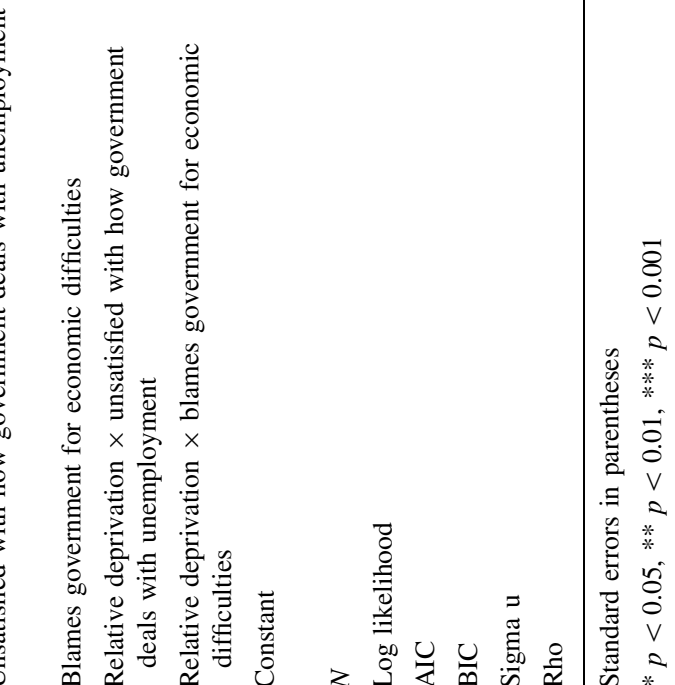




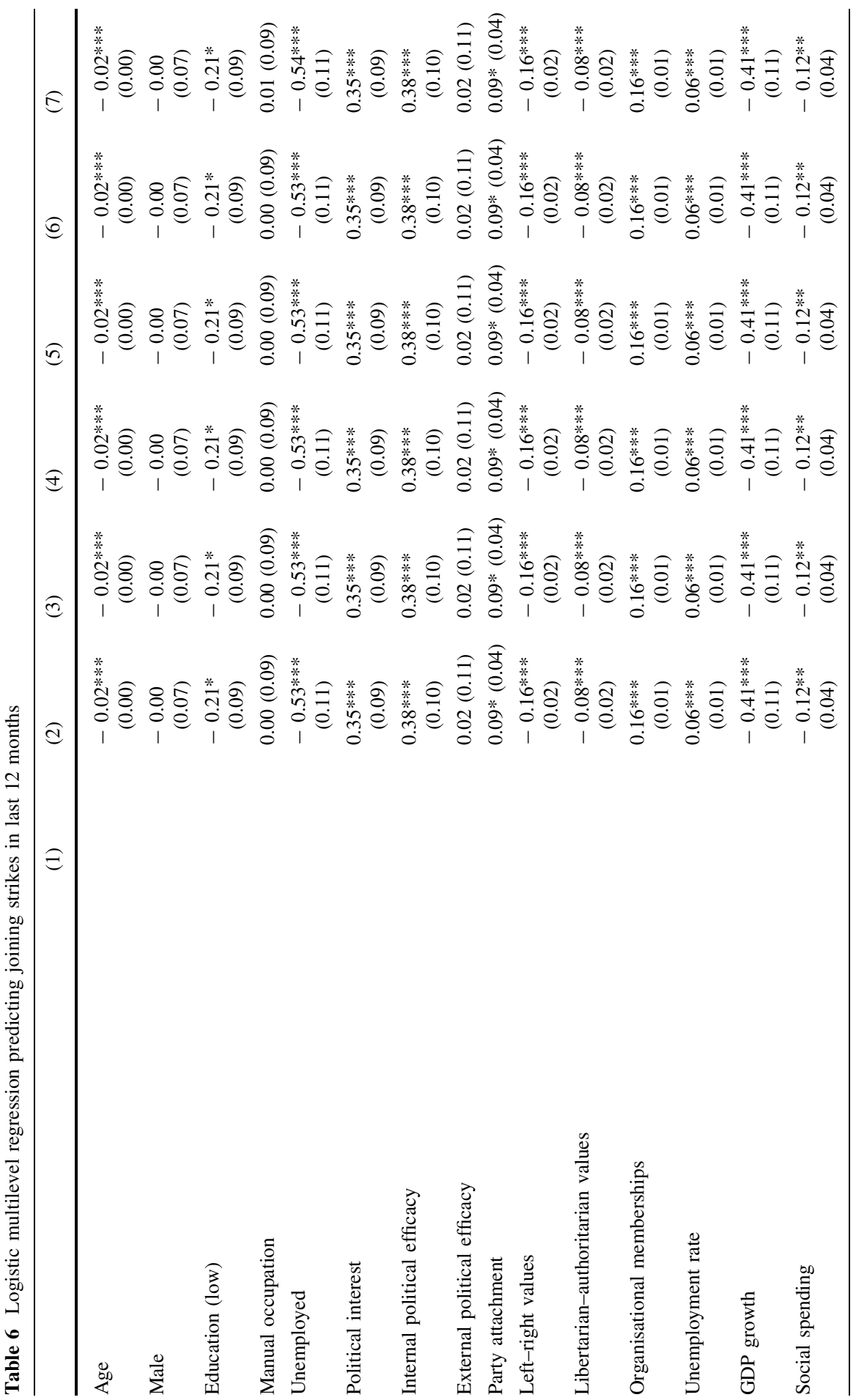




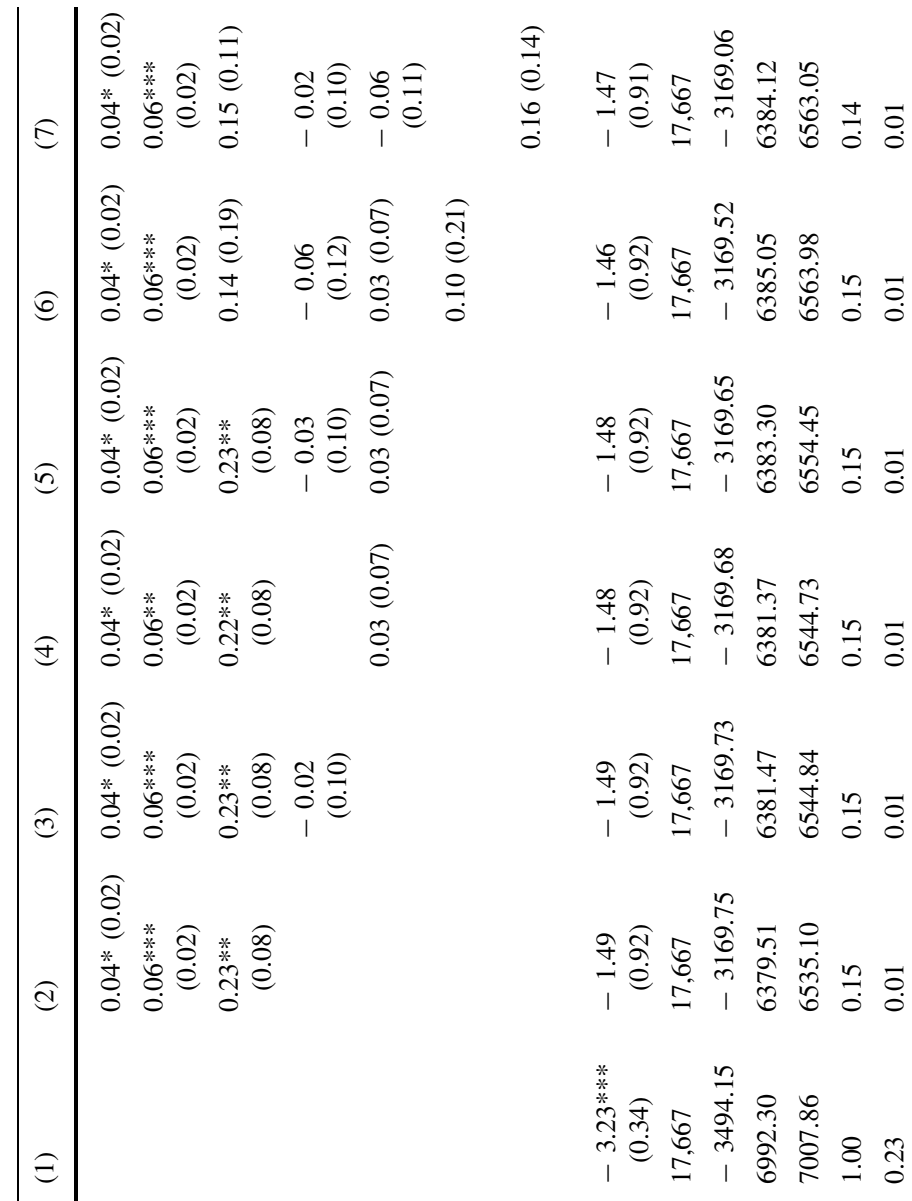

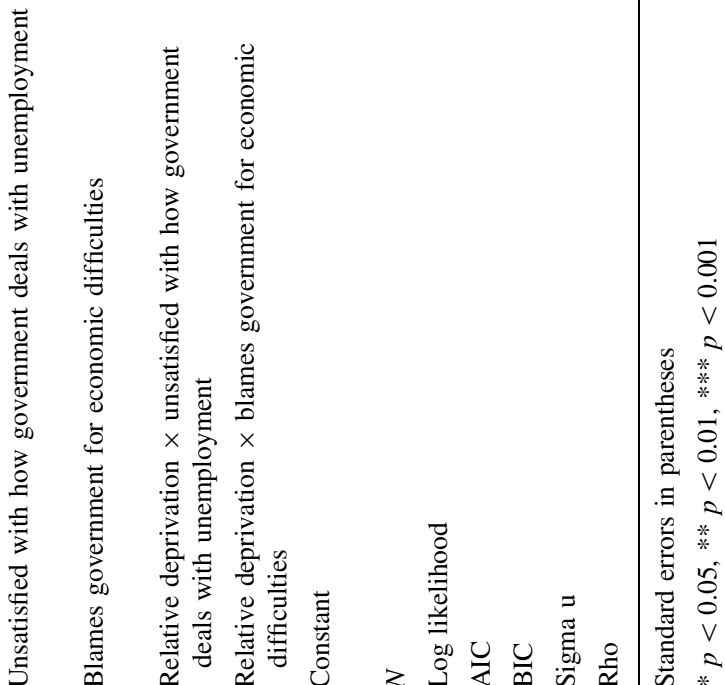


unemployment and of blaming the national government for the nation's economic difficulties. However, such an effect varies across types of political behaviour, being strongest for the more institutionalised forms, and more specifically for voting against the incumbent, that is, for the electoral form. The more contentious forms of political behaviour are less influenced by perceptions of the role of the government in the economic crisis.

If we look at the interaction terms (third hypothesis), we observe a significant effect of the interaction between relative deprivation and dissatisfaction with the way the government deals with the crisis in the case of voting against the incumbent (Table 4). This means that the effect of relative deprivation on economic voting is conditional upon believing that the government has not dealt with the crisis in a satisfactory way. We also observe a significant interaction term in the case of attending political meetings (Table 4). Again, dissatisfaction with the way the government deals with the crisis significantly interacts with relative deprivation. Like for voting against the incumbent, although to a lesser extent, here the effect of relative deprivation seems to be conditional upon perceptions of the role of government in the crisis. More specifically, the effect of government performance on unemployment is significant also in the case of attending political meetings. In contrast, the interaction between relative deprivation and blame assignment is not significant either for voting against the incumbent nor for attending political meetings. Furthermore, none of the two interactive terms displays a statistically significant effect on participating in demonstrations and joining strikes, indicating

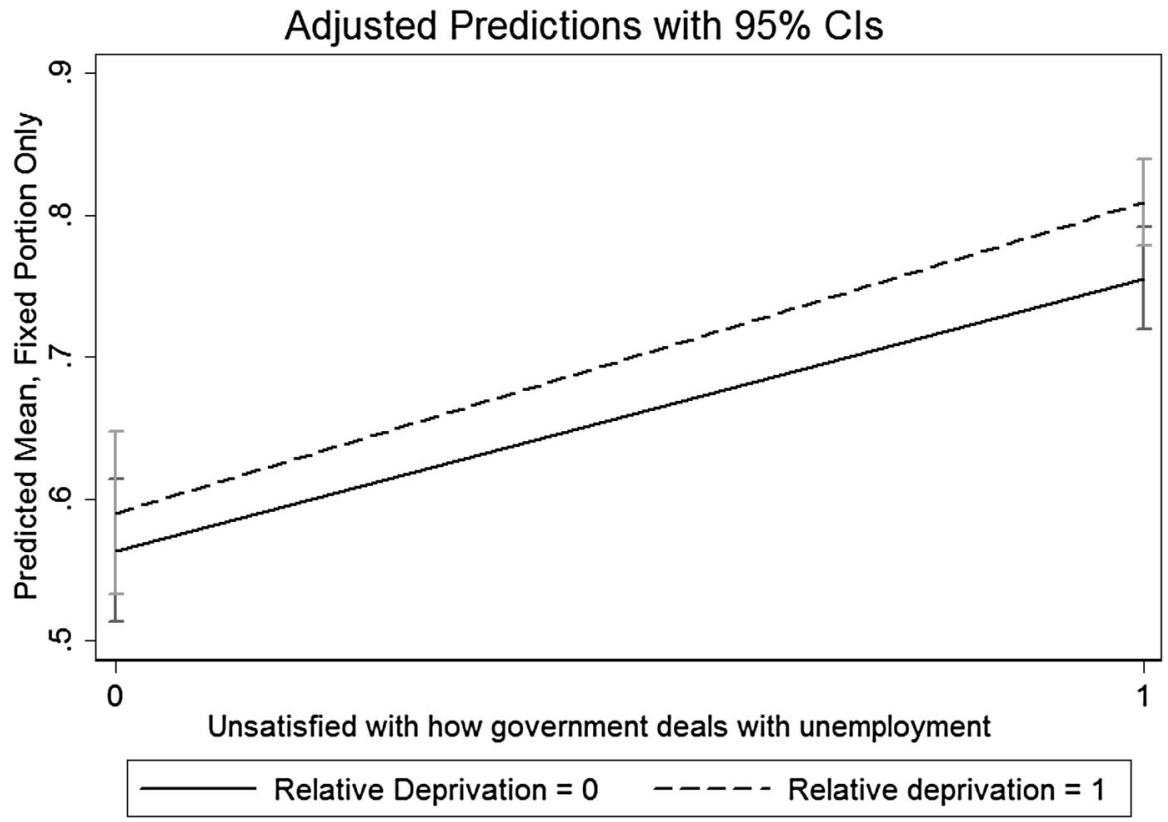

Fig. 1 Plot of interaction between relative deprivation and dissatisfaction with how government deals with unemployment on voting against the incumbent. Note adjusted predicted means based on Model 6 in Table 3 


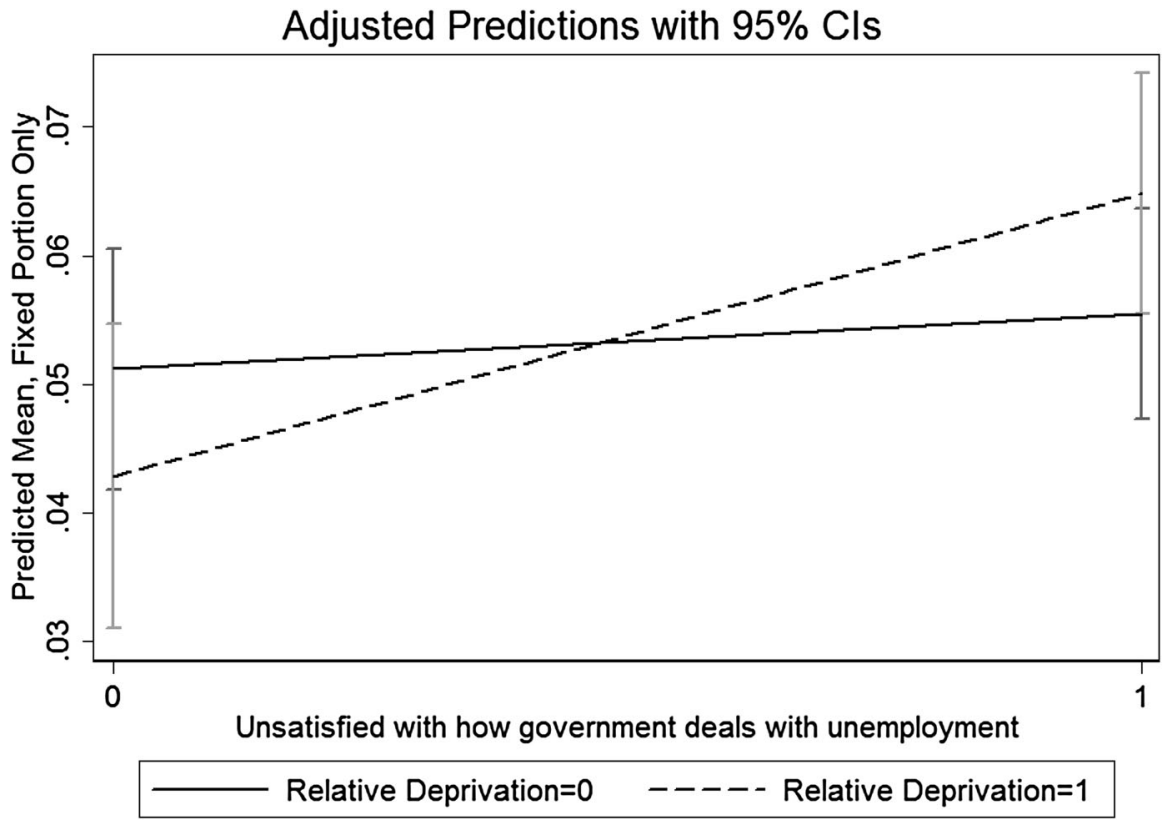

Fig. 2 Plot of interaction between relative deprivation and dissatisfaction with how government deals with unemployment on attending public meetings. Note adjusted predicted means based on Model 6 in Table 4

that there is no conditional effect of perceptions of the government's role in the crisis on the relationship between feelings of relative deprivation and involvement in these more contentious forms of political behaviour. Our third hypothesis is therefore confirmed only in part, namely for the two more institutional form of political behaviour and in the case of the conditional role of dissatisfaction with government performance, while blame assignment does not seem to matter here.

Conditional effects can be seen more clearly in Figs. 1 and 2, which show the plots of the two statistically significant interaction terms. Here we can better appreciate the direction and size of such effects. As we can see, the conditional role of perceptions of the role of government, while present both in the case of voting against the incumbent and in the case of attending political meetings, is particularly visible for the latter. This can be seen by comparing the slope for those who feel deprived with the slope for those who do not feel deprived. The latter is nearly flat, whereas the former shows a strong effect of relative deprivation on this form of political behaviour. In brief, overall we can see that dissatisfaction with the way the government is dealing with unemployment matters both for those who feel deprived and for those who do not feel deprived. However, the former are more likely to engage than the latter, especially so when it comes to attending political meetings. This pattern, furthermore, is present only in the more institutionalised forms of political behaviour, whereas relative deprivation does not interact with perceptions of the role of government in the economic crisis when it comes to the more contentious forms. 


\section{Conclusion}

The deep economic crisis suffered by many European countries in recent years has spurred much scholarly writing on the impact of this particular crisis and of economic crises in general (for e.g. see English et al. 2016; Giugni and Grasso 2017b, c; Grasso and Giugni 2016a; Temple et al. 2016; Temple and Grasso 2017). In this paper, we have explored a number of potential effects on different types of political behaviour, which can all be seen as the political expression of dissatisfaction with the current political and economic situation, using an original dataset stemming from a survey conducted in nine European countries. We were particularly interested in investigating the impact of perceptions of the government's role in the crisis (as measured through satisfaction with the way the government is dealing with unemployment, and blaming the government for the economic situation of the country), as well as their interaction with perceptions about one's own economic conditions in terms of relative deprivation (as measured through the feelings that the economic situation of the household is worse than 5 years earlier). Moreover, we have looked at the effects of these predictors and their interactions on various forms of political behaviour: an electoral form captured by voting against the incumbent and three non-electoral kinds of participation, namely attending public meetings, participating in demonstrations, and joining strikes.

Our findings suggest that perceptions of the government's role in the crisis are instrumental in pushing people to manifest their disapproval politically. At the same time, however, the impact of these variables is not homogeneous across all forms of political behaviour, as for some-in particular, voting against the incumbent-they matter, while not so for other modes. Most importantly, we found evidence that the perceptions people have of the way in which the government is dealing with the situation, more precisely on the way in which it is dealing with unemployment-a key aspect of the economy in times of crisis-conditions the effect of relative deprivation on political behaviour. This occurs namely with voting against the incumbent and with attending public meetings, that is, the more institutionalised forms of political behaviour, whether electoral or non-electoral.

While we expected such a conditional effect to occur for other forms as well, the variations we observed both in the main effects and in the interaction effects across forms of political behaviour allow us to stress another important point. This is to say that different forms of political behaviour are influenced by different factors. In other words, the economic crisis led people to participate politically, but in different forms and for different reasons pertaining to the way they perceived the crisis and its effects.

Finally, on a more methodological note, our study shows the need to go beyond the traditional distinction between electoral and non-electoral political behaviours and also to consider certain forms of electoral behaviour such as voting against the incumbent as a form of adversarial political action alongside other forms such as attending a meeting, demonstrating, or participating in a strike. We argue that the political context of an action has important repercussions for how we understand it 
in terms of its contentiousness. As others before us have argued (Heaney and Rojas 2014; Hutter 2014; Kriesi 2014; McAdam and Tarrow 2010), electoral politics and protest politics need to be studied together in order to arrive at a better understanding of why and how citizens hold governments to account, both in times of crisis as well as in more "ordinary" times.

Acknowledgements Results presented in this paper have been obtained within the project "Living with Hard Times: How Citizens React to Economic Crises and Their Social and Political Consequences" (LIVEWHAT). This project was funded by the European Commission under the 7th Framework Programme (Grant Agreement No. 613237). The authors are grateful to Eva Anduiza and Katrin Uba for their detailed comments on an earlier draft of this paper as well as to all the participants of the Paper Presentation Workshop at the Project Meeting of LIVEWHAT, Scuola Normale Superiore, Florence, 3-4 December, 2015. We also would like to thank two anonymous referees for their useful suggestions. The usual disclaimers apply.

Open Access This article is distributed under the terms of the Creative Commons Attribution 4.0 International License (http://creativecommons.org/licenses/by/4.0/), which permits unrestricted use, distribution, and reproduction in any medium, provided you give appropriate credit to the original author(s) and the source, provide a link to the Creative Commons license, and indicate if changes were made.

\section{References}

Alvarez, R.M., and J. Nagler. 1995. Economics, Issues and the Perot Candidacy: Voter Choice in the 1992 Presidential Election. American Journal of Political Science 39: 714-744.

Bennett, W.L. 2012. The Personalization of Politics: Political Identity, Social Media, and Changing Patterns of Participation. Annals of the American Academy of Political and Social Science 644: 20-39.

Bernburg, J.G. 2015. Economic Crisis and Popular Protest in Iceland, January 2009: The Role of Perceived Economic Loss and Political Attitudes in Protest Participation and Support. Mobilization 20: 231-252.

Brady, H. 1999. Political Participation. In Measures of Political Attitudes, ed. J. Robinson, P. Shaver, and L. Wrightsman. Burlington, NJ: Academic.

Brady, H., S. Verba, and K.L. Scholzman. 1995. Beyond SES? A Resource Model of Political Participation. American Political Science Review 89: 271-294.

Brody, R.A., and P.M. Sniderman. 1977. From Life Space to Polling Place: The Relevance of Personal Concerns for Voting Behavior. British Journal of Political Science 7: 337-360.

Campbell, A., P.E. Converse, W.E. Miller, and D.E. Stokes. 1960. The American Voter. New York: Wiley.

Dalton, R.J., A. Van Sickle, and S. Weldon. 2010. The Individual-Institutional Nexus of Protest Behaviour. British Journal of Political Science 40: 51-73.

Davies, J. 1962. Towards a Theory of Revolution. American Sociological Review 27: 5-19.

Duch, R.M. 2007. Comparative Studies of the Economy and the Vote. In The Oxford Handbook of Comparative Politics, ed. C. Boix, and S.C. Stokes. Oxford: Oxford University Press.

Dunn, A., M.T. Grasso, and C. Saunders. 2014. Unemployment and Attitudes to Work: Asking the 'right' Question. Work, Employment and Society 28: 904-925.

English, P., M.T. Grasso, B. Buraczynska, S. Karampampas, and L. Temple. 2016. Convergence on Crisis? Comparing Labour and Conservative Party Framing of the Economic Crisis in Britain, 2008-2014. Politics and Policy 44: 577-603.

Feldman, S. 1982. Economic Self-Interest and Political Behavior. American Journal of Political Science 26: 446-466.

Fiorina, M.P. 1981. Retrospective Voting in American National Elections. New Haven, CT: Yale University Press. 
Geschwender, J. 1968. Explorations in the Theory of Social Movements and Revolutions. Social Forces 47: $127-135$.

Giugni, M., and M.T. Grasso (eds.). 2015a. Austerity and Protest: Popular Contention in Times of Economic Crisis. London: Routledge.

Giugni, M., and M.T. Grasso. 2015b. Environmental Movements in Advanced Industrial Democracies: Heterogeneity, Transformation, and Institutionalization. Annual Review of Environment and Resources 40: 337-361.

Giugni, M., and M.T. Grasso. 2016. How Civil Society Actors Responded to the Economic Crisis: The Interaction of Material Deprivation and Perceptions of Political Opportunity Structures. Politics and Policy 44: 447-472.

Giugni, M., and M.T. Grasso (eds.). 2017a. Citizens and the Crisis: Perceptions, Experiences, and Responses to the Great Recession in Europe. London: Palgrave Macmillan.

Giugni, M., and M.T. Grasso. 2017b. Citizens and the Crisis: Perceptions, Experiences, and Responses to the Great Recession in Nine Democracies. In Citizens and the Crisis: Perceptions, Experiences, and Responses to the Great Recession in Europe, ed. M. Giugni, and M.T. Grasso. London: Palgrave Macmillan.

Giugni, M., and M.T. Grasso. 2017c. Citizens and the Crisis: The Great Recession as Constraint and Opportunity. In Citizens and the Crisis: Perceptions, Experiences, and Responses to the Great Recession in Europe, ed. M. Giugni, and M.T. Grasso. London: Palgrave Macmillan.

Grasso, M.T. 2011. Political Participation in Western Europe. D.Phil. Thesis, Nuffield College, University of Oxford.

Grasso, M.T. 2013. The Differential Impact of Education on Young People's Political Activism: Comparing Italy and the United Kingdom. Comparative Sociology 12: 1-30.

Grasso, M.T. 2014. Age-Period-Cohort Analysis in a Comparative Context: Political Generations and Political Participation Repertoires. Electoral Studies 33: 63-76.

Grasso, M.T. 2016a. Generations, Political Participation and Social Change in Western Europe. London: Routledge.

Grasso, M.T. 2016b. Political Participation. In Developments in British Politics 10, ed. R. Heffernan, P. Cowley, and C. Hay. Basingstoke: Palgrave Macmillan.

Grasso, M.T. 2018. Young People's Political Participation in Times of Crisis. In Young People Regenerating Politics in Times of Crisis, ed. S. Pickard, and J. Bessant. London: Palgrave Macmillan.

Grasso, M.T., and M. Giugni. 2016a. Do Issues Matter? Anti-austerity Protests' Composition, Values, and Action Repertoires Compared. Research in Social Movements, Conflicts and Change 39: 31-58.

Grasso, M.T., and M. Giugni. 2016b. Protest Participation and Economic Crisis: The Conditioning role of Political Opportunities. European Journal of Political Research 55: 663-680.

Grasso, M.T., S. Farrall, E. Gray, C. Hay, and W. Jennings. 2017. Thatcher's Children, Blair's Babies, Political Socialisation and Trickle-Down Value-Change: An Age, Period and Cohort Analysis. British Journal of Political Science. https://doi.org/10.1017/S0007123416000375.

Gurr, T.R. 1970. Why Men Rebel. Princeton, NJ: Princeton University Press.

Heaney, M.T., and F. Rojas. 2014. Party in the Street: The Antiwar Movement and the Democratic Party After 9/11. Cambridge: Cambridge University Press.

Hellwig, T. 2010. Elections and the Economy. In Comparing Democracies 3: Elections and Voting in the 21st Century, 3rd ed, ed. L. LeDuc, R.G. Niemi, and P. Norris. Thousand Oaks, CA: Sage.

Hutter, S. 2014. Protesting Culture and Economics in Western Europe: New Cleavages in Left and Right Politics. Minneapolis, MN: University of Minnesota Press.

Iyengar, S. 1991. Is Anyone Responsible? How Television Frames Political Issues. Chicago: University of Chicago Press.

Kaase, M., and A. Marsh. 1979. Political Action: A Theoretical Perspective. In Political Action: Mass Participation in Five Western Democracies, ed. S. Barnes, and M. Kaase. Beverly Hills, CA: Sage.

Kern, A., S. Marien, and M. Hooghe. 2015. Economic Crisis and Levels of Political Participation in Europe (2002-2010): The Role of Resources and Grievances. West European Politics 38: 465-490.

Kiewiet, D.R. 1983. Macroeconomics and Micropolitics: The Electoral Effects of Economic Issues. Chicago: University of Chicago Press.

Kinder, D.R., and D.R. Kiewiet. 1979. Economic Discontent and Political Behavior: The Role of Personal Grievances and Collective Economic Judgments in Congressional Voting. American Journal of Political Science 23: 495-527.

Klandermans, B., J. van Stekelenburg, and J. van der Toorn. 2008. Embeddedness and Identity: How Immigrants Turn Grievances into Action. American Sociological Review 73: 992-1012. 
Kriesi, H. 2014. The Political Consequences of the Economic Crises in Europe: Electoral Punishment and Popular Protest. In Mass Politics in Tough Times: Opinions, Votes and Protest in the Great Recession, ed. N. Bermeo, and L.M. Bartels. Oxford: Oxford University Press.

Levin, I., J.A. Sinclair, and R.M. Alvarez. 2015. Participation in the Wake of Adversity: Blame Attribution and Policy-Oriented Evaluations. Political Behavior. https://doi.org/10.1007/s11109015-9316-6.

Lewis-Beck, M.S. 1988. Economics and Elections: The Major Western Democracies. Ann Arbor, MI: University of Michigan Press.

Lewis-Beck, M.S., and M. Paldam. 2000. Economic Voting: An Introduction Electoral Studies 19.2-3: 113-121. In Special Issue: Economics and Elections, eds. M.S. Lewis-Beck and M. Paldam. https:// doi.org/10.1016/S0261-3794(99)00042-6.

Lewis-Beck, M.S., and M. Stegmaier. 2000. Economic Determinants of Electoral Outcomes. Annual Review of Political Science 3: 183-219.

Lewis-Beck, M.S., and M. Stegmaier. 2007. Economic Models of Voting. In The Oxford Handbook of Political Behavior, ed. R. Dalton, and H.-D. Klingemann. Oxford: Oxford University Press.

Lohmann, S. 1994. The Dynamics of Informational Cascades: The Monday Demonstrations in Leipzig, East Germany, 1989-91. World Politics 47: 42-101.

Malhotra, N., and Y. Margalit. 2010. Short-Term Communication Effects or Long-Standing Dispositions? The Public's Response to the Financial Crisis of 2008. Journal of Politics 72: 852-867.

Margalit, Y. 2013. Explaining Social Policy Preferences: Evidence from the Great Recession. American Political Science Review 107: 80-103.

McAdam, D., and S. Tarrow. 2010. Ballots and Barricades: On the Reciprocal Relationship Between Elections and Social Movements. Perspectives on Politics 8: 529-542.

Meyer, D.S. 2004. Protest and Political Opportunities. Annual Review of Sociology 30: 125-145.

Pattie, C., P. Seyd, and P. Whiteley. 2004. Citizenship in Britain: Values, Participation and Democracy. Cambridge: Cambridge University Press.

Peffley, M. 1984. The Voter as Juror: Attributing Responsibility for Economic Conditions. Political Behavior 6: 285-294.

Popp, E., and T.J. Rudolph. 2011. A Tale of Two Ideologies: Explaining Public Support for Economic Interventions. Journal of Politics 73: 808-820.

Rüdig, W., and G. Karyotis. 2013. Who Protests in Greece? Mass Opposition to Austerity. British Journal of Political Science. https://doi.org/10.1017/S0007123413000112 (available on CJO).

Saunders, C., M.T. Grasso, C. Olcese, E. Rainsford, and C. Rootes. 2012. Explaining Differential Protest Participation: Novices, Returners, Repeaters and Stalwarts. Mobilization 17: 263-280.

Skocpol, T., and V. Williamson. 2013. The Tea Party and the Remaking of Republican Conservatism. New York: Oxford University Press.

Sniderman, P., and R. A. Brody. 1977. Coping: The ethic of self-reliance. American Journal of Political Science 21: 501-521.

Snijders, T., and R. Bosker. 1999. Multilevel Analysis: An Introduction to Basic and Advanced Multilevel Modelling. London: Sage.

Tarrow, S. 1996. States and Opportunities: The Political Structuring of Social Movements. In Comparative Perspectives on Social Movements: Political Opportunities, Mobilizing Structures, and Cultural Framings, ed. D. McAdam, J. McCarthy, and M.N. Zald. Cambridge: Cambridge University Press.

Temple, L., and M.T. Grasso. 2017. Austerity, Politics, and Partisanship in the UK. In Citizens and the Crisis: Perceptions, Experiences, and Responses to the Great Recession in Europe, ed. M. Giugni, and M.T. Grasso. London: Palgrave Macmillan.

Temple, L., M.T. Grasso, B. Buraczynska, S. Karampampas, and P. English. 2016. Neoliberal Narrative in Times of Economic Crisis: A Political Claims Analysis of the UK Press, 2007-2014. Politics and Policy 44: 553-576.

Thomassen, J. 1989. Economic Crisis, Dissatisfaction, and Protest. In Continuities in Political Action: A Longitudinal Study of Political Orientations in Three Western Democracies, ed. M.K. Jennings, J.W. van Deth, S. Barnes, D. Fuchs, F.J. Heunks, R.F. Inglehart, M. Kaase, H.-D. Klingemann, and J.J.A. Thomassen. New York: de Gruyter.

Welzel, C., and F. Deutsch. 2012. Emancipative Values and Non-violent Protest: The Importance of "Ecological" Effects. British Journal of Political Science 42: 465-479.

Wolfinger, R., and S. Rosenstone. 1980. Who Votes?. New Haven, CT: Yale University Press. 